\title{
"Competitive Study of Service Quality Based on the Perception of Customers and Management of Islamic Banks in Pakistan"
}

\author{
Chaudhry Kashif Mahmood ${ }^{1}$, Tayyiba Khalil ${ }^{2}$, Abdulghani Ali Al-Hattami ${ }^{3}$ \\ ${ }^{1}$ Lecturer: Deanship of Education Development, University of Dammam, Dammam, Saudi Arabia \\ ${ }^{2}$ Lecturer: Alumni and Career Development Centre,University of Dammam, Dammam, Saudi Arabia \\ ${ }^{3}$ Assistant Professor: Deanship of Education Development, University of Dammam, Dammam, Saudi Arabia
}

\begin{abstract}
Service quality has become a highly debatable issue in banking industry all over the world. Several researches are there which indicate that high service quality is pivotal to achieve organizational profitability. Therefore, banks are trying to achieve high service quality by understanding customers' perception towards their products and services and to satisfy and retain the customers accordingly.This study is conducted to measure the level of service quality of Islamic banks in Pakistan by following the Compliance, Assurance, Reliability, Tangibility, Empathy and Responsiveness (CARTER) model approach. In Islamic banking it is called Islamic SERVQUAL. The difference in the perception of customers and employees regarding service quality is also included in this study. This is a primary research based on the data directly collected from the customers and employees of Islamic banks, operating in the city of Lahore. The study contains discussion on general idea of Islamic bankingand service quality. Descriptive related to Compliance, Assurance, Reliability, Tangibility, Empathy and responsiveness are calculated and described. Individual and overall significance is examined by using $t$-Stats for each element of the model and as a whole. The results indicate that there is significant difference between the perception of customers and management regarding the service quality of Islamic banks. Keywords: Service quality, Islamic Banks, CARTER Model.
\end{abstract}

\section{Introduction}

Since 1990 Islamic banking has made a tremendous progress in the financial market but it is still facing a stiff competition from conventional banking industry. Banks are providing wide range of products to build a competitive edge in the market place moreover, customers' expectations are increasing, therefore service quality has become one of the most important ingredients of marketing mix (Hussain \& Leo, 2009).

The concept of service quality has become a highly debatable issue all over the world. Researches indicate that high quality services considerably contribute towards the profitability of organizations. Customer has become the key element of organizational strategies because the income depends upon the retention and satisfaction of the customer, so organizations pay special attention towards customers' satisfaction. In this scenario banks are investigating customers' needs and expectations regarding service quality (Lodhi and Kalim, 2005).

In Pakistan, banking sector is based on two systems namely i.e.: Islamic Banking and Conventional Banking. Conventional banking system is based on predetermined return on the investments and deposits, mainly deals with interest that is prohibited in Islamic Shari'ah. The use of interest, either usury or commercial interest, creates frustration, injustice, unequal distribution of wealth, immoral values, economic disasters, unfair prices of commodity as well as inflation in the market. For elimination of interest to overcome these evils, a new concept of Islamic banking was introduced (Ahmad, Malik, \& Humayoun, 2010).

Islamic Banking is characterized as interest free banking system with spirit, ethics and value system of Islam, established and governed under the principles laid down by the Islamic Shari'ah. It derives its inspiration and guidelines from Islam and conducts its operations in accordance with Shari'ah(Moin, 2008). The paradigms of Islamic principles are profit and loss sharing and prohibition of Riba ${ }^{1}$ (additional compensation without any due consideration). Islamic banks cannot deal in transactions which involve Gharar (excessive level of uncertainty due to lack of information), Maiser (gambling) as well as invalid transaction that is Haram in the eyes of Islam (Suleman \& Nasser, 2001). The main concept is that Islam does not sanction any predetermined profit on the investment but permits predetermined profit sharing ratio (Lodhi \& Kalim, 2005).

${ }^{1}$ Riba is categorized in two parts: Riba- an-Nasiyah and Riba-al-Fadl.

Riba- an-Nasiyah is concerned with predetermined rate of interest, received by lender against loan.

Riba-al-Fadl is concerned with an additional compensation without consideration resulting from a transaction of commodities. 
Due to existence of two banking systems, a complex and dynamic environment is created. Banks are focusing on a wide range of products with high quality services to meet customers' expectations (Ahmed \& Kashif-ur-Rehaman, 2010). Whenever Islamic banks or commercial banks launch a new product or service, its success is based on the level of customer satisfaction towards that product or service (Khattak \& Kashif-urRehamn, 2010).

The purpose of this study is to assess the level of service quality provided by the Islamic banks in Pakistan according to the perception of customers and management

And to explore the difference in the perception of employees and customers regarding service quality. Previously, Othman \& Owen (2001)conducted a research to measure the service quality of Islamic banks in Kawait in which CARTER Model was formed with the help of SERVQUAL Model. SERVQUAL model was developed by theParasuramane, Zeithaml, \& Berry (1985), based on five dimensions namely: Assurance, Responsiveness, Tangibility, Empathy and Reliability. Othman and Owen (2001) argued that Islamic banking is based on Islamic Shari'ah principles therefore, an additional dimension 'Compliance' should be included in SERVQUAL to measure the service quality of Islamic banking which resulted in the formation of CARTER Model. CARTER Model is based on six dimensions namely: Compliance, Assurance, Reliability, Tangibility, Empathy and Responsiveness.

As Othman (2003) recommended the model to measure the level of service quality of Islamic banks, the study focuses on CARTER Model approach to observe the perception of customers and amanagement towards service quality.

\section{a. Service Quality}

\section{Literature Review}

The $\mathrm{ISO}^{2} 9000: 2000^{3}$ standard defines quality as, "The ability of a set of intrinsic characteristics to satisfy requirements". Quality, in practice is based on two factors: external quality and internal quality. External quality in concerned with customer satisfaction. It requires that the delivery of product and service fulfills customers' expectations and make them loyal towards the organization whereas, internal quality is concerned with the continuous improvement of organizational internal affairs. It ensures the implementation of the means that improvement is anticipative step in delivery of service with any additional cost (Norman \& Fuqua, 2003).

Lake and Hickey (2002) found that in the highly competitive and dynamic environment, winners are those who condense the customers cynisim by exceeding customers expectations. Those firms are making rapid progress because their center of attention is long term investment by paying special attention to service quality. They not only encourage the growth of customers but retain them for a longer period of time.

Ibrahim, Joseph, \& Ibeh (2006)conducted a research on customers' perception of electronic service delivery in the UK retail banking sector and found that banks have directed to flourish in non-Islamic markets. They further argued that this should add to the competitiveness of this market; require a closer look at the opinion of the Muslims towards Islamic banking in the UK, which support these new established Islamic banks to develop their service and products in order to improve customers' perception and satisfaction.

Srevice quality has been considered as an essential component in the service industry because it has been recognized as a driver of corporate marketing and financial performance to flourish the financial market (Buttle, 1996). Ogunnaike \& Olaleke (2010)revealed that technological integration affects the service quality so banks are making efforts to change their mechanism and establishing technological advancement to deliver the quality services to the customers. They further suggested that banks management should develop experienced, knowledgeable and proficient human resource that can accurately deal with the operations of the bank.

Adlaigan \& Buttle (2002)reported that Gronroos (2003) has been consistent about the assumed dimensionality of service quality, which is based on customers' perception of service encounter and consider three dimensions:

- Functional quality of the service process is concerned with how the services are provided to the customers.

- Technical quality is concerned with outcome of the exchange process i.e. what is received by customers.

- The image of the service provider is concerned with general perception of customers about supplier.

Parasuramane, Zeithaml and Berry (1985) considered that a customers' judgment towards service quality is based on the gap between the expected quality services and perceived service. There was however little understanding of the differences between the concept of quality in the manufacturing industry and the concept of quality in the service industry. Service industry has several important characteristics that differentiate it from manufacturing in terms of quality. These characteristics includeintangibility, heterogeneity, simultaneity and Perishability.

\footnotetext{
${ }^{2}$ The International Organization for Standardization ${ }^{3}$ ISO 9000:2000, Quality Management Systems.
} 
Pararuraman, Berry, \& Zeithmal (1991)developed SERVQUAL model to measure the service quality which consists of five dimensions: reliability, responsiveness, tangibility, security and empathy. The SERVQUAL model is based on twenty-two questions to make a difference between the customer's perception and perceived service quality. Buttle (1996) argued that SERVQUAL's five dimensions to measure the service quality have not authenticated completely. Researchers included additional dimensions in the orginal model because five dimensions of the model cannot define the service quality. Othman and Owen (2001) found that the Islamic Banking Industry consists of Islamic principles therefore; an additional dimension should be included in SERVQUAL to measure the service quality of Islamic banking. Othman (2003) later developed a new model known as CARTER Model to measure the service quality in Islamic banking. CARTER was comprised of five dimensions as used in SERVQUAL model and one dimension added namely; compliance.

- Compliance: Compliance means "Compliance with Islamic Law".

- Assurance: Employees' knowledge, courtesy, credibility, competence, ability to inspire trust and confidence

- Reliability: Consistency of performance, dependability of services, accuracy of record and information, good manners, sympathy, resolving customer complaints and service charges.

- Tangibility: Physical evidence of the services such as physical facilities, equipment, appearance of personnel, appearance of the interior and exterior of the banks facilities

- Empathy: Account access, communication and understanding the customers need

- Responsiveness: Willingness or readiness of employees to help customers, prompt service, accessibility of credit on favorable conditions and branch network.

From the review of literature it is found that service quality is the key element for customer satisfaction and loyalty towards the Islamic banking. Organizations are paying special attention towards the quality of products and services to retain the customer for longer time period. It is also asserted that customers' satisfaction is a difference between the expectations and perception after the use of product and services. Shari'ah compliance, employees' behavior and attitude, banking hours, branch network, confidentiality, security and individual concentration of bank's management towards the customers are the basic factors to measure the service quality.

\section{Theoretical Framework}

\section{a. Research Question}

1. What is the level of service quality of Islamic banks in Pakistan; perception of customers and management?

2. Is there any significant difference between the perception of employees and customers regarding service quality?

\section{b. Research Hypothesis}

$\mathrm{H}_{0}$ : There is no significant difference between the perception of customers and management of Islamic banks about service quality.

$\mathrm{H}_{1}$ : There is a significant difference between the perception of customers and management of Islamic banks about service quality.

\section{c. Methodology}

The study is quantitative in nature, whereby it measures the level of service quality of Islamic banks. It is a primary research where the level of service quality in the perception of customers and management are studied.

The main focus of this study is customers and management of Islamic banks in Pakistan. The banks are selected from the list provided by the State Bank of Pakistan in which five banks i.e. Meezan Bank, Bank Islami Pakistan, Albaraka Islamic Bank, Dubai Islamic Bank and Al-Buraj Bank are working as Islamic banks. The data are collected form branches of Islamic banks working in the city of Lahore.

Non-probability sampling technique is used to collect the data from the management and customers of Islamic banks.Non-probability sampling is used in this research because the samples are gathered in the research process do not give all the individuals in the population equal chances of being selected. The estimated sample size of 600 on 85 branches is applied in the region of Lahore. After one month struggle of the researcher, a total response of 529 (354 customers and 175 managers) has been received.The data are analyzed through Mean, Standard Deviation as well as independent sample t-test.

To observe the level of service quality of Islamic banks, questionnaire of CARTER Model (Islamic SERVQUAL) is adopted and developed through 5 points Likert Rating Scale from Strongly Disagree to Strongly Agree (Strongly Disagree:1, Disagree:2, Neutral:3, Agree:4, Strongly Agree:5) and analyzed by using SPSS. 


\section{d. Reliability of Data}

35 questions are floated to check the reliability of instrument. Cronbatch's Alpha is used to measure the reliability of the instrument that is $92 \%$.

\section{e. Research Model}

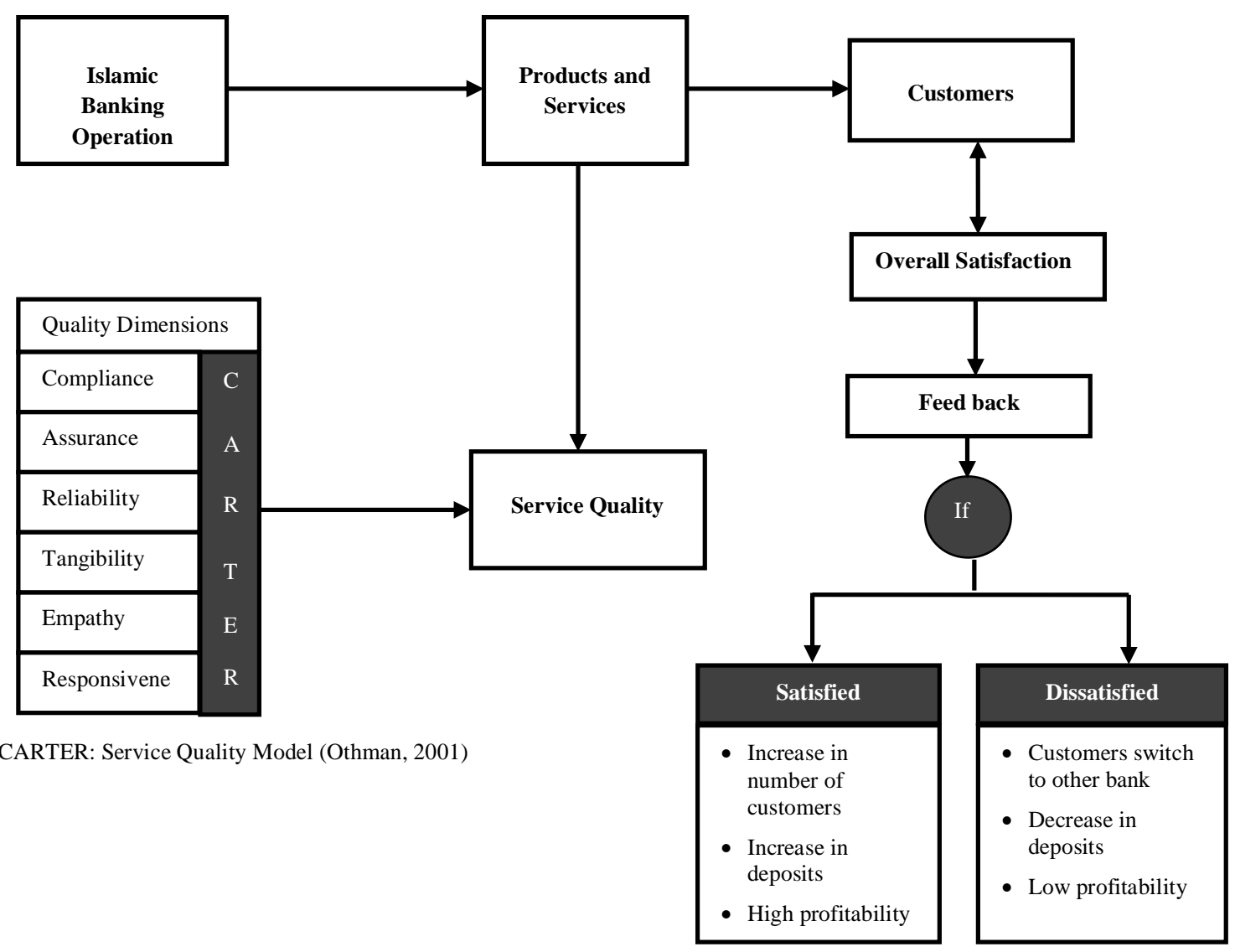

IV. Results

Table 1: Respondents (Customersand Management)

\begin{tabular}{|l|l|l|l|l|}
\hline \multirow{2}{*}{ Banks } & Customers & Management \\
\cline { 2 - 5 } & Frequency & Percent & Frequency & Percent \\
\hline Meezan Bank & 134 & 37.9 & 46 & 26.3 \\
\hline Al-Baraka Bank & 100 & 28.2 & 39 & 22.3 \\
\hline Dubai Islamic Bank & 62 & 17.5 & 29 & 16.6 \\
\hline Bank Islami Pakistan & 27 & 7.6 & 35 & 20.0 \\
\hline Al-Buraj Bank & 31 & 8.8 & 26 & 15.9 \\
\hline Total & 354 & 100.0 & 175 & 100.0 \\
\hline
\end{tabular}

Table1; shows the number of respondents i.e. customers and management. Out of 529, there were 354 customers $(66.9 \%)$ and 175 managers $(33.1 \%)$. The results indicate that the major portion of respondents consists of customers. Out of 354, there were 134 customers and 46 managers from Meezan Bank, 100 customers and 39 managers from Al-Baraka Bank, 62 customers and 29 managers from Dubai Islamic Bank, 27 customers and 35 managers from Bank Islami, 31 customers and 26 managers from Al-Buraj Bank. The results indicate that the major portion of respondents in terms of customers was from Meezan Bank and Al-Baraka Bank. 
Table 2: Gender

\begin{tabular}{lllllll}
\hline & Customer & \multicolumn{3}{c}{ Management } \\
\cline { 2 - 7 } & $\mathrm{f}$ & $\%$ & $\mathrm{f}$ & $\%$ & $\mathrm{f}$ & $\%$ \\
\hline Male & 269 & 76.0 & 134 & 76.6 & 403 & 76.2 \\
Female & 85 & 24.0 & 41 & 23.4 & 126 & 23.8 \\
\hline Total & 354 & 100.0 & 175 & 100.0 & 529 & 100.0 \\
\hline
\end{tabular}

Table 2; shows the distribution of respondents by gender. Out of 529, there were 403 males $(76.2 \%)$ and 126 females $(23.8 \%)$. It also shows the distribution of customers and management by gender. Out of 354 , there were 269 males $(76 \%)$ and 85 females (24\%). In management perspective out of 175, there were 134 males $(76.6 \%)$ and 41 females $(23.4 \%)$. It indicates that the major portion of customers and management by gender consist of males.

Table 3; Mean Score and Standard Deviation of Service Quality Dimensions

\begin{tabular}{|l|l|l|l|l|}
\hline \multirow{2}{*}{ Dimensions } & \multicolumn{2}{|l|}{ Customers } & \multicolumn{2}{l|}{ Management } \\
\cline { 2 - 5 } & Mean & S.D & Mean & S.D \\
\hline Compliance & 2.06 & .623 & 4.15 & .535 \\
\hline Assurance & 3.83 & .612 & 4.35 & .481 \\
\hline Responsiveness & 2.96 & .443 & 4.06 & .345 \\
\hline Tangibility & 3.86 & .523 & 4.21 & .520 \\
\hline Empathy & 2.99 & .598 & 4.14 & .636 \\
\hline Reliability & 3.17 & .616 & 3.91 & .602 \\
\hline
\end{tabular}

Table 3; indicates the mean score and standard deviation for service quality dimensions. Results specify that customers' means score in all dimensions of service quality is low whereas management mean score in all dimensions is high which means customer's perception towards the service quality offered by the Islamic banks does not match with management perception and there is a significant difference among the opinions of customers and management. It also revealed that in Compliance, Responsiveness and Empathy customers are disagreed with management opinion.

Table 4; Level of Service Quality

\begin{tabular}{|c|c|c|c|c|}
\hline \multirow{2}{*}{ Dimension } & \multicolumn{2}{|c|}{ Customer } & \multicolumn{2}{|c|}{ Management } \\
\hline & Mean & S.D & Mean & S.D \\
\hline Service Quality & 3.14 & .357 & 4.96 & .344 \\
\hline
\end{tabular}

Table 4; indicates the mean score and standard deviation regarding service quality for customers (3.14) with standard deviation (.357) for management (5.14) with standard deviation (.344). It shows that management mean is significantly greater than customer's mean. Results indicate that management has a strong perception regarding the provision of services quality but customers disagreed.

Table 4.1: Independent Sample T-Test against Service Quality

\begin{tabular}{|c|c|c|c|c|c|c|c|}
\hline \multirow[b]{2}{*}{ Variable } & \multicolumn{7}{|c|}{ t-test for Equality of Means } \\
\hline & $\mathrm{F}$ & Sig & $\mathrm{t}$ & df & $\begin{array}{l}\text { Sig. (2- } \\
\text { tailed) }\end{array}$ & $\begin{array}{l}\text { Mean } \\
\text { Differenc } \\
\text { e }\end{array}$ & $\begin{array}{l}\text { Std. Error } \\
\text { Differenc } \\
\text { e }\end{array}$ \\
\hline $\begin{array}{l}\text { Service Quality } \\
\text { Equal variances assumed }\end{array}$ & .859 & $\begin{array}{l}.35 \\
4 \\
\end{array}$ & -30.428 & 527 & .000 & -.99162 & .03259 \\
\hline $\begin{array}{l}\text { Equal variances not } \\
\text { assumed }\end{array}$ & & & -30.823 & $\begin{array}{l}358.8 \\
3\end{array}$ & .000 & -.99162 & .03217 \\
\hline
\end{tabular}

Table 4.1; indicates the results of Independent Sample t-test towards the level of service quality. Results show thatcustomer's opinion regarding service quality is significantly different than the management $\left(\mathrm{t}_{527}=-30.428\right.$, 
$\mathrm{p}<0.05, \mathrm{p}=0.000$ ). The management mean was higher than the customers' mean score in all dimensions of service quality.

\section{Conclusion}

Results indicate that there is a significant difference between the perception of customers and management. Management has a constant perception about the service quality but customer's opinion shows a discrepancy according to the nature of services.

Analysis of management views in terms of compliance, assurance, tangibles, reliability, responsiveness and empathy about their respective banks revealed that managers agreed that banks are providing service quality in a better way. Their responses are almost near to strongly agree, which means managers seek no gap of service quality while analysis of customers' opinions about their banks showed that customers' mean is significantly low in all dimensions. Customers' opinion revealed that banks are providing service quality but not as management said. Most of the customers disagreed about the service quality of their banks but at the same time management mean were highly greater than customers which means there exist a service quality gap according to customers but management is not ready to admit their banks. Customers' responses give a clear picture of service quality in all sub-scales which need a high attention of the banks service quality department to improve their service quality according to customers' perspective to meet the competitive edge in a competitive environment.

Customers ranked tangibility as the most important dimension such as modern technology for the delivery of products, convenient working hours, separate departments and counters, appealing outlook and efficient transactions to the customers. Assurance ranked as the second most important dimension such as staff treatment of customer, fast and efficient counter services, staff give individual attention to the customers and customers' business needs. On the other hand, customers ranked compliance as the least important dimension of service quality.

Banking sector has become the backbone of financial market in the whole world but Islamic banking industry still facing problems. Now, Islamic banks are striving to make competitive advantage in the industry by providing wide range of products with quality services. This study is conducted to observe customers satisfaction with reference to service quality offered by the Islamic banks in Pakistan. This study is quantitative in nature providing valuable information to the policy makers, researchers, practitioners and the general public.

\section{References}

[1]. Adlaigan, A. H., \& Buttle, F. A. (2002). SYSTRA-Q: A new measure of bank service quality. International Journal of ServiceIndustry, vol: 13(4), 362-381.

[2]. Ahmad, A., Malik, M. I., \& Humayoun, A. A. (2010). Banking devlopment inPakistan: A journey from conventional to islamic banking. European Journal ofSocial Science, 17.

[3]. Ahmed, A., \& Kashif-ur-Rehaman. (2010, June). An imperical investgaion of islamicbanking in Pakistan based on perception of service quality. Aferican Journal ofBusiness Management, 1185-1193.

[4]. Buttle, F. (1996). SERVQUAL: review, critique, research agenda. European Journalof Marketing, Vol: 30 (1), PP 8-32.

[5]. Gronroos, C. (2003). A service quality model and its marketing implications.European Journal of Marketing, Vol: 18(4), 36-44.

[6]. Hussain, M., \& Leo, S. (2009). Customer perception on service quality in retailbanking in Middle East: A case of Qatar.

[7]. International Jouranal of Islamic andMiddle Eastrn Finance \& Management, Vol 2, 338-350.

[8]. Ibrahim, E. E., Joseph, M., \& Ibeh, K. I. (2006). Customers' perception of electronicservice delivery in the UK retail banking sector. International Journal of BankMarketing, Vol: 24 (7), 475-493.

[9]. Khattak, N., \& Kashif-ur-Rehamn. (2010, May). Customer satisfaction andAwareness of Islamic Banking in Pakistan. AfericanJournal of BusinessManagement, 662-671.

[10]. Lodhi, S., \& Kalim, R. (2005, Winter). Stretgic direction for developing an Islamicbanking system. The Pakistan DevelopmentReview, 44; 1003-1020.

[11]. Moin, M. S. (2008). Performance of Islamic banking and Conventional Banking inPakistan.

[12]. Norman, \& Fuqua. (2003). START ISO 9000:2000. Vol: 9 (13).

[13]. Ogunnaike, \& Olaleke, O. (2010). The Relationship Between Service Quality AndCustomer Satisfaction;Evidence From Nigerian Banking Industry. Global Journal ofManagement and Business Research. 10(3) P2.

[14]. Othman. (2003). Adopting and measuring the Service quality in Islamic Banking: Acase study of Kawait Finance House.

[15]. International Jouranal of Islamic Finance, Vol:3

[16]. Othman, A. Q., \& Owen, L. (2001). Adopting and measuring the Service quality inIslamic Banking: A case study of Kawait Finance House. International Journal ofIslamic Financial, Vol: 3.

[17]. Pararuraman, A., Berry, L., \& Zeithmal, v. (1991). perceived service quality as acustomer-based performance measure: An empirical examination of organizationalbarriers using an extended service quality model. Human Recouce Management, pp.335-364.

[18]. Parasuramane, A., Zeithaml, V., \& Berry. (1985). A Conceptual Model of ServiceQuality and its Implication for Future Research. Journal of Marketing, 41-50.

[19]. Suleman, \& Nasser, M. (2001). Corporate governance in islamic banking. Quartelyjournal of Budapest university of Scienceaand Public Administration, Vol:22 No. 3. 